\title{
Kinas nye energisamarbejde
}

Martin Hvidt

\section{Kinas økonomi boomer. For at imødekomme den stigende efterspørgsel har Kina etableret en ny og aktiv Mellemøstpolitik, der skal sikre landets næsten umættelige energibehov}

Kina har været selvforsynende med olie frem til 1993, hvorefter landet i stigende grad begyndte at importere. I 2003 nåede importen op på 2 mio. tønder per dag, hvilket ikke er meget set i forhold til USA's import på næsten 11 mio. tønder. Men Kinas fremtidsudsigter er mere foruroligende. Forventningen er, at landet vil importere 10 mio. tønder olie per dag i år 2025, hvilket svarer til den mængde olie, Saudi-Arabien producerer dagligt. Disse perspektiver har fået Beijing til i 2003 at lave en såkaldt Twenty-first Century Oil Strategy, der for det første introducerer begrebet "energisikkerhed" og for det andet har øremærket 100 mia. dollars til at sikre sig nye energiressourcer rundt om i verden, herunder i Mellemøsten. I dag importerer Kina $51 \%$ af sin olie fra Mellemøsten, og den helt overvejende del af denne olie kommer fra tre lande, Saudi-Arabien, Iran og Oman.

\section{Kinas samkvem med Mellemøsten}

Kina er langt fra en ny spiller i Mellemøsten. I 1950'erne og 1960'erne kunne Kinas rolle ses som et ideologisk korstog, hvor landet så sig selv som leder af de socialistiske tredjeverdenslande - en revolutionær avantgarde, hvis mål var at sprede en marxistisk-leninistisk ideologi. I denne periode ydede Kina støtte til socialistiske ledere som fx den ægyptiske præsident Nasser og til bevægelser som PLO og den mindre kendte Popular Front for the Liberation of Oman.

Fra 1970'erne lagde Kina i stigende grad vægt på Mellemøsten som aftagermarked for kinesiske produkter og arbejdskraft. Omkring 1990 var der således mere end 50.000 kinesiske arbejdere i Golf-landene. Mht. til eksporten til Mellemøsten så gjaldt den både produkter som fx tekstiler og lavteknologiske maskiner og i stigende grad våben. 
Kina formåede at etablere en betydelig våbeneksport til lande som Syrien, Libyen, Iran og Irak - lande som havde svært ved at indkøbe våben på det internationale marked. Der stod således Made in China på en betydelig del af de missiler, Iran og Irak afskød mod hinanden i krigen 1980-1988, og Kina menes endvidere at have været en væsentlig leverandør af teknologi til de irakiske og iranske kemiske og atomare forskningsprogrammer. Våbenleverancerne aftog dog i løbet af 1990'erne bl.a. som følge af pres fra USA.

I 1950'erne og 1960'erne betragtede Kina endvidere Mellemøsten som en kampplads for dets ideologiske opgør med Sovjetunionen. Konsekvensen var bl.a. at Kina forsøgte at underminere Sovjetunionen i de lande, hvor det søgte indflydelse. Således støttede kineserne fx præsident Sadat i Ægypten og præsident Asad i Syrien.

\section{Langsigtede samarbejdsrelationer}

Omkring år 2000 synes Kina at have påbegyndt en ny fase i sit forhold til Mellemøsten - en fase, der kan betegnes "olie-diplomati." Denne politiske strategi går ud på at sikre olieleverancer på et marked, hvor udbuddet stort set er identisk med efterspørgslen. Eller mere præcist: At overbevise de mellemøstlige lande om, at de bør sælge deres olie til Kina frem for til andre lande, som står i kø for at købe, herunder ikke mindst USA, der ligesom Kina forudser et væsentligt stigende behov for at importere olie i fremtiden.

Det kinesiske middel til at opnå dette mål er at opbygge langsigtede samarbejdsrelationer med udvalgte lande i regionen. Og det søger de at gøre gennem en udenrigspolitik, der er "ikke-vestlig" og bygger på et betydeligt statsligt engagement.

Den vestlige dagsorden i Mellemøsten - i hvert fald i den amerikanske version - bygger på at promovere demokrati og menneskerettigheder, hvilket af selvindlysende grunde ikke er punkter på den kinesiske dagsorden, ligesom Kina hverken har moralske skrupler ved at besidde en majoritetsandel i den sudanske olieindustri, på trods af statens folkemord i Dafur-provinsen, eller aktivt at modvirke, at sagen om Irans kernekraftvåben i 2004 blev bragt for FN's Sikkerhedsråd. I takt med at Mellemøstens stater lægges under pres fra Vesten for at reformere deres politik og økonomi, forsøger Kina at placere sig som et værdineutralt alternativ til de vestlige lande. Som en rapporter fra avisen Times of Oman skrev i forlængelse af det Kinesisk-Arabiske Økonomiske Forum, afholdt den 13.-15. april 2005 i Beijing, "bekræftede mødet, at den kinesiske regering er opsat på at etablere økonomiske alliancer, der ikke bygger på politik."

Anden del af strategien bygger som næunt på den kinesiske regerings statslige engagement $i$ at sikre 
sig leverancer. På produktions- og raffineringssiden er oliesektoren kendetegnet ved at være drevet af private firmaer, der nøje overvejer indtjeningsmulighederne, før de byder på koncessioner eller ingår andre aftaler. Kina, derimod, intervenerer i oliemarkedet med to statsligt ejede selskaber, og deres bestræbelser på at sikre sig leverancer bakkes ikke blot op af statslige midler, men også af statslige handelsorganisationer.

Der er således en række eksempler på, at Kina har betalt overpriser for koncessioner eller for aktier i olieudvindingsprojekter i Mellemøsten. Endvidere gøres langsigtede olieaftaler til en del af bredere handelsaftaler, hvor olien udgør betaling for kinesisk eksport af en lang række andre varer og tjenesteydelser og ikke mindst udenlandske investeringer til den arabiske region.

\section{Forholdet Kina og Saudi-Arabien}

Sidste år investerede Kina 5 mia. dollars i Saudi-Arabien. Saudi-Arabien, der er Kinas væsentligste olieleverandør, har opgjort deres behov for udenlandske investeringer til 173 mia. dollars. Den udenlandske kapital skal sikre udbygning af $\mathrm{fx}$ elektricitetsværker, vandforsyning og anden infrastruktur, og kineserne har vist sig villige til at foretage sådanne investeringer og stille deres ekspertise og arbejdskraft til rådighed i forbindelse med opførelsen tekniske anlæg.
Kineserne skal bl.a. stå for opbygningen af Saudi-Arabiens mobilnet, ligesom Kina er leverandør af teknisk personale til at udbygge og vedligeholde olieinstallationer. SaudiArabien og Kina indgik i 1990 en aftale om salg af olie, som i løbet af 1990'erne er gengældt ved, at Kina har solgt ballistiske missiler til SaudiArabien.

Golfens samarbejdsråd (GCC) er på nippet til at integrere sit marked yderligere gennem dannelsen af en egentlig monetær union. Dette er planlagt til at ske i 2006. Parallelt med dette forbereder GCC og Kina sig i øjeblikket på at etablere et frihandelsområde. Set med begge parters øjne er der utroligt store gevinster at hente: GCC har $45 \%$ af verdens oliereserver, som Kina herved får forbedret adgang til, og markedet i GCC vil profitere af billige varer og tjenesteydelser fra Kina.

Selv uden dette frihandelsområde forventes Kinas handel med Mellemøsten at tredobles fra 36 mia. dollars til over 100 mia. dollars over de næste fem år.

\section{Forholdet Kina og Iran}

Kinas forhold til Iran bygger på mere end 20 års samarbejde. Kina har som tidligere næunt leveret våben og teknologi til Irans kemiske og atomare våbenprogrammer. Salget af våben er efter alt at dømme stoppet og er langsomt blevet erstattet af handel med olie og varer. 
Således meddelte Iran blot to dage efter Bushs genvalg i 2004, at det havde underskrevet en 30-årig aftale med Kina om olie og gasleverancer for 100 mia. dollars. Mens detaljerne i aftalen ikke er kendte, indeholder den sandsynligvis samme elementer som aftalerne med GCC-landene, nemlig en ugennemsigtig blanding af statslige handelsaftaler, udenlandske investeringer og leverancer af et bredt spektrum af varer og tjenesteydelser fra kinesisk side. Der er ingen tvivl om, at den diplomatiske støtte, som Kina ydede Iran i sagen om dets atomprogram har været medvirkende årsag til, at denne handelsaftale blev indgået.

Udformningen af Kinas oliediplomati synes ikke særligt overraskende. For det første har Kina fået gode kort på hånden pga. det afkølede forhold mellem USA og Mellemøsten og i særdeleshed USA's anstrengte forhold til Saudi-Arabien efter terrorangrebene den 11. september 2001. Kina har således vist sig både hurtig og effektiv til at udnytte den mulighed, som herved opstod for at profitere af deres "ikke-vestlige" dagsorden.

For det andet havde Kina ikke mange andre valg. Landet har skullet sikre sine olieleverancer og dermed etablere sine samarbejdsrelationer til Mellemøsten i en situation, hvor vestlige olieselskaber stort set har været eneste operatører siden
1908, hvor den først oliekoncession blev underskrevet i Iran. I forsøget på at få en fod inden for i regionen, har Kina måttet satse på investeringsmarkeder, som kommercielle vestlige selskaber ikke har kunnet eller villet gå ind på, fx i Sudan og Iran.

Kina kan således betragtes som en late-comer i regionen, og har som sådan været tvunget til at satse på de mere marginale markeder.

Hvorvidt Kinas Mellemøstpolitik vil blive en succes på længere sigt, afhænger i høj grad af, hvordan Vestens forhold til Mellemøsten udvikler sig. Meget taler for, at jo mere Vesten med USA i førersædet presser på for demokratiske og menneskerettighedsmæssige reformer, jo større sandsynlighed vil der være for, at Kinas strategi bliver en succes.

Og tidsfaktoren er vigtig: Jo længere tid Kina har til at opbygge sine handelsrelationer, jo bredere og dybere vil disse blive, og jo større sandsynlighed er der for, at samkvemmet vil opnå det momentum, der skal til for, at det kan fortsætte, selv med ændrede signaler fra Vesten.

Kina har allerede i dag etableret sig som en væsentlig spiller i regionen, og væksten i den kinesiske økonomi tyder på, at dets evne til at agere i regionen forbedres dag for dag.

Martin Hvidt er Ph.D. og lektor ved Center for Mellemøststudier, Syddansk Universitet. 